\title{
Principle Of Freedom Of Contract In Public Contract
}

\author{
Rumi Suwardiyati \\ Faculty of Law \\ Brawijaya University \\ Malang, Indonesia \\ rumisuwardiyati@ub.ac.id
}

\author{
Setiawan Wicaksono \\ Faculty of Law \\ Brawijaya University \\ Malang, Indonesia \\ setiawanwicaksono@ub.ac.id
}

\author{
Ranitya Ganindha \\ Faculty of Law \\ Brawijaya University \\ Malang, Indonesia \\ r.ganindha@at.ub.ac.id
}

\begin{abstract}
Freedom of contract is embedded to each individual involved in a contract making. When it is related to a contract between government and its partner, the contract should bring equity and justice to both parties, and no one should be harmed or disadvantaged. This is categorised as normative juridical research with statute and conceptual approaches. The primary legal data obtained involved Article 1338 Paragraph (1) of Civil Code concerning the principles of freedom of contract. The conceptual approach, however, is closely related to defining the concept of freedom of contract. The freedom of contract is defined as the contract that still refers to the scope in which it is not against the law, public order, morality, and appropriateness. The freedom of contract itself is intended to bring welfare for society
\end{abstract}

Keywords-contract, public contract, principle of freedom of contract

\section{INTRODUCTION}

With its abundant natural resources, skilful human resources, hospitality, and conflict-free archipelago, Indonesia has attracted many investors. The investment that has been done is surely inseparable from contract which is made to provide legal certainty by all parties involved. Indonesia complies with civil law in contract making and refers to Civil Code (further stated as KUHPdt). The contract regulated in Book III of KUHPdt does not clearly mention contract but it rather states 'agreement' as regulated in Article 1313 of KUHPdt: "an agreement is an action where a person or more is bound with another person or more."

The above definition of an agreement indicates that an agreement is a legal action that involves at least two parties and this agreement is binding for all parties[1]. Therefore, agreement consists of the following 6 (six) aspects[2]:

1. There must be parties involved. The parties involved in an agreement are called as subjects of agreement of at least two people or more. People or legal entities can represent as subjects that hold authority to conduct legal action as regulated in Acts;

2. There must be agreement among parties involved;

3. There must be achievement planned. Achievement is a responsibility that has to be fulfilled by all parties according to what is required in the agreement;

4. There must be written and oral form, as the agreement holds legal force when it is provided in both forms mentioned.

5. There must be specific requirements;
6. The agreement must have objectives to be achieved as provided in the content of the agreement per se.

Contract is the form of an agreement, stemming from too wide a scope of definition. Contract and agreement, however, can be clearly distinguished based on their characteristic and form[3]. Contract is made in a written form because all parties concerned call for legal certainty and the contract itself is expected to serve as a proof in case of disputes. A contract is often aimed for business where much profit is the main objective.

Some experts differentiate between contract and agreement because contract is only restricted to written form. The term contract or agreement is mostly compared to contract and agreement in Anglo-American system. Agreement is defined in similar way the contract is in AngloAmerican. Agreement is defined as overeenskomst in Dutch. Agreement holds wider scope of meaning than contract. When an agreement regulates business activities, it is then defined as a contract. However, agreement not related to business activities remains as an agreement[4].

One of the parties involved in a contract can be government, in which the government is as public or private legal entity. The contract made by the government and its partner is typical and has multi-aspects. Despite the contractual relationship between the government and its partner, the contract itself contains not only private law but also public law. In making a contract, there should be principles that must be followed, one of which is the freedom of contract. The principles are enacted in Article 1338 Paragraph (1). Although it is not clearly mentioned, 'all agreements' legally made according to Act for those involved in the contract are emphasised. The word 'all' is where the freedom of contract starts. The 'all', according to experts, is defined as not against the law, public order, and morality.

However, it is still questioned whether the government and its partner as parties involved in the contract making, still can make contract without limit. This question brings the authors to the study with the title 'Principle of Freedom of Contract in Public Contract'.

\section{DISCUSSION}

This research is categorised as normative juridical legal research employing statute, conceptual, and case approaches. Normative legal research is defined as a research that puts 
the law as a structure of norms including principles, rules of legislation, court decisions, agreements, and doctrines[5]. This research will be more focused on the freedom of contract which involves the government. The government serves as a public and private legal entities which are mainly intended to facilitate the interests of society. Moreover, all parties in the contract represent private sectors and partners that hold equal rights to implement the principles of the freedom of contract.

Before the $19^{\text {th }}$ century, the principle was recognised by Europeans where it was first introduced not by a legal expert, but a philosopher. This principle first came up from the natural law mainstream, emphasising that human beings, who were equal to nature, could survive on their own, not by the help of a community. "With unlimited intention for each individual, the juridical relationship emerged". Since the revolution of France, the principle has greatly evolved with its motto liberte, egalite and fraternite, and the government's interference was quite apparent.

The inception of the freedom of contract was marked by the development that brought the policy of liberalism. In the past, the policy extended its area of investment of European private capital to be invested in its colonialized countries. The Dutch, for example, colonialized Indonesia where such a policy was brought along. The freedom of contract is then equally defined as the one emerging from the principle of liberalism.

As according to the principle of individualism, every individual has a right to get what he/she desires. In contract law, this philosophy is reflected through the freedom of contract. The theory "laisssez fair" regards that the invisible hand guarantees free competition principle, in which the government did not interfere with social life and economy of the societies. The principle of individualism has given an opportunity to those with good economic position to control those with poor economic condition, as stated in "exploitation de I'homme per I'homme".

The principle of the freedom of contract is enacted in Book III of KUHPdt of Article 1338 Paragraph (1) of KUHPdt. Book III of KUHPdt refers to open system, in which freedom is given to those making a contract to manage the contract that will be made, which is unlike Book II of KUHPdt regulating an object that should not be infringed. This open system is reflected from Article 1338 Paragraph (1) stating "all agreements made legally serve as Act for those who made the agreement". The word 'all' is a legitimation of the freedom of contract. The freedom of contract, as the name suggests, provides a freedom for all parties to make an agreement of all forms and formats, with whoever might be involved in the contract and related to the substance of the contract[6].

It is concluded that the regulation in book III of Civil Code, especially related to contract or agreement that fits commercial activity due to its open characteristic. Therefore, the principle of freedom of contract and law are relevant to each other[7].

The scopes of freedom of contract, according to law, are presented as follows[8]:

1. the freedom to make or not to make an agreement;

2. the freedom to decide with whom a person will make an agreement;
3. the freedom to determine the substance of the planned agreement;

4. the freedom to determine an object;

5. the freedom to determine form

6. the freedom to accept or break the provisions of complementary Act

Making a contract is not only based on the existing principles, but it should also consider the eligibility of a contract, which is regulated in Article 1320 KUHPdt that consists of four conditions:

a) Agreement;

b) Competence;

c) Certain matters and;

d) Halal object.

Agreement holds two elements: offer and acceptance. Offer and acceptance can be categorised into an agreement from which a contract stems. An agreement takes equal intentions from all parties concerned, equal thoughts and equal agreement without any force, fraudulence, and blunder[9]. The inception of an agreement is elaborated through the following theories[10]:

\section{Wils Theorie (Will Theory)}

Will is defined as delivering the intention aimed to create an agreement that is clearly and assertively stated.

\section{Verklaring Theorie (Statement Theory)}

This theory is more emphasised on the statement of a party to another. The statement expressed is based on the will of the party that makes the statement. Therefore, the statement that can be used as a tool to assess the emergence of an agreement is the statement with the will[11].

\section{Vertrouwens Theorie (Trust Theory)}

This is a statement that receives response from the opposite party and to receive trust that what is stated is what is really desired.

\section{Verzendings Theorie (Delivery Theory)}

This theory is based on the idea that an agreement that occurs during the delivery and acceptance or an offer. The time when the answer regarding the acceptance of an offer is accepted becomes the benchmark of an agreement.

\section{Ontvangst Theorie (Acceptance Theory)}

An agreement is regarded as born when an answer is accepted regarding the offer delivered.

\section{Vernemings Theorie (Knowledge Theory)}

This theory emerges when a party that offers is aware of the acceptance of the offer. This theory is similar to acceptance theory[12].

Competence is related to subject and maturity. The legal subject is categorised into two, a person and a legal entity. In this case, the government serving as a public or private legal entity or a partner, and maturity is related to the age limit at which a person is eligible to perform legal action. The maturity is only related to a party as individual, not business entity. Regarding the business entity, what matters is whether the business entity holds the legal entity. This difference is 
essential in case of legal consequence due to dispute or loss. When the contract embraces only people, not business entities, maturity of the individuals is involved in the contract matter, as maturity determines whether or not an individual is eligible to take legal action. The basis regarding maturity is regulated in Article 1330 jo 330 of KUHPdt.

Object as mentioned in number three and four must be determinable and the halal object is related to any cause that is allowed. Article 1333 of Civil Code implies that the object in the agreement is the object agreed by all parties. An object of agreement must be determined or at least it can be determined[13]. Halal object is enacted in Article 1337 of Civil Code that implies an understanding related to halal object that must not be against the Act, morality, and public order. Principally, halal object is not cause and effect that are found in daily habit, which gives clue about what is behind legal circumstances and the change in it. However , the law has never lies behind the making of contract. The law is only related to the achievent to be implemented, as it is regulated in the contract that is not against Act, morality, and public order[14].

All conditions of contract mentioned must be fulfilled, or not completely fulfilled conditions will lead to legal consequences, where the contract can be cancelled when the first and second conditions are not fulfilled, while failure in fulfilment of number three and four leads to the state of invalid from the outset or the contract will be taken as never existing. Failing to fully understand the principle of freedom of contract will lead to injustice and imbalance. Every party involved in a contract must have equal position and bargaining position.

The government who holds power of a state can serve as either public or private legal entity. As a private legal entity, the government could perform legal action that is regulated in civil law regarding the act to purchase, sell, lease, and make an agreement. The contract performed by the government and its partner must be objective in terms of its substance. The government must pay attention to whether the contract also brings welfare to its society. The principle of freedom of contract does not mean that the government has unlimited freedom to make a contract.

The freedom still certainly gives limit in contract for both the government and its partner. The government as the representative of its people must fully and carefully understand the meaning of freedom of contract so that people will not be disadvantaged due to the contract made.

Contract-related case can be seen from an example of contract between a government and PT. Freeport Indonesia, where the government holds the status as a private legal entity that also holds an equal position to its partner. Specifically the mining contract is regulated in Article 33 Paragraph (3) of the Constitution of the Republic of Indonesia stating that earth, waters, and other natural resources contained therein are controlled by a state and utilised for the sake of the welfare of the people. The Constitution gives command to the government to manage earth for the welfare of Indonesian people. The substance of the contract must be pro-society, meaning that following the principle of freedom of contract is not necessarily to fully give the private company freedom to manage the natural resource. The principle of freedom should be defined in a more positive way in which the government must have strong bargaining position to achieve equal contract.

Moreover, the government must be more selective and more pro-society. The contract must involve the local communities not only in permit issuing process, but society must be present in the contract made. A freedom with no limit will only bring to dispute. When freedom is implemented according to its literal meaning, there will certainly be conflict of interests within. In the process, the freedom of contract is not only restricted by Acts, but also by doctrine, jurisprudence, and the extended definition of good faith, appropriateness, acceptable morality, common interest, and accepted causes[15].

Kolectivering is a group of people formed to protect people of a weak position in a contract with those having strong economic position. It proves that the principle of freedom of contract will not be appropriate for the party making the contract to prioritise. In its development, the freedom of contract is restricted to conditional freedom for the sake of the society involved in the contract making.

Although there is a tendency that restricts the freedom of contract, this tendency has introduced important role into the understanding of propriety and feasibility (redelijk heid en bijlijkheid). Good moral (gooden zeden) and public order are also to be taken into account.

However, it does not mean that this restriction causes the principle of the freedom of contract to be abrogated or broken. From the formal perspective, the freedom of contract still applies but the substance or clause from contractual relationship is determined by combination of rules. Contract law will be more into public in which the nuance of private interests will transform into common interests[16]. The freedom of contract still needs to maintain as the main principle in a contract law in Indonesia. The Pancasila Philosophy shows that there should be harmony, uniformity, and balance between rights and obligations. In other words, there is a responsibility within the freedom[17].

The government as a party involved in a public contract must implement the principle of the freedom of contract along with the responsibility and the capability to maintain balance with the purpose that the contract made is able to reach the welfare and absolute happiness relevant to the common interests of the societies and social welfare.

\section{CONCLUSION}

The principle of the freedom of contract still has its restriction and it does not necessarily mean freedom without limits. Specifically, mining contract, in which one of the parties in the contract is government, must be understood that the freedom of contract must still be in line with existing Acts, public order, and morality.

The government as a public or private entity must be able to formulate the freedom of contract. The definition given to the term freedom must be positive for the welfare of society, and the definition must not only be restricted to common interests or group interests, as stated in Article 33 Paragraph (3) of Constitution of the Republic of Indonesia stating that the government manages natural resources wholly for the sake of the welfare of society. The most essential part to ponder regarding mining contract made by the government 
and private sectors or investors is that the contract is made for the welfare of the people of Indonesia.

\section{REFERENCES}

[1] K. Muljadi and G. Widjaja, Perikatan Yang Lahir dari Perjanjian. Jakarta: PT. Raja Grafindo Persada, 2003

[2] S. Mertokusumo, Mengenal Hukum. Yogyakarta: Liberty, 1999.

[3] Yasardin, Asas Kebebasan Berkontrak Syariah. Jakarta: Prenadamedia, 2018

[4] P. M. Marzuki, "Batasan Kebebasan Berkontrak," J. Yuridika, vol. 18, no. 3 May, pp. 195-196, 2013.

[5] M. Fajar and Y. Achmad, Dualisme Penelitian Hukum Normatif dan Empiris. Yogyakarta: Pustaka Pelajar, 2013.

[6] F. F. Adonara, Aspek-Aspek Hukum Perikatan. Bandung: CV. Mandar Maju, 2014.

[7] M. Isnaeni, Seberkas Diorama Hukum Kontrak. Surabaya: PT. Revka Petra Media, 2018.

[8] S. R. Sjahdewi, Kebebasan Berkontrak dan Perlindungan yang Seimbang Bagi Para Pihak dalam Perjanjian Kredit Bank di Indonesia. Jakarta: Institut Bankir Indonesia, 1993.

[9] Subekti, Hukum Perjanjian. Jakarta: Intermasa, 1998.
[10] I. Soerodjo, Hukum Perjanjian dan Pertanahan, Perjanjian Build, Operate and Tranfer Atas Tanah (Pengaturan, Karakteristik dan Praktek). Yogyakarta: LaksBang PRESSindo, 2016

[11] Suryodiningrat, Asas-Asas Hukum Perikatan. Bandung: Tarsito, 1985.

[12] A. Miru, Hukum Kontrak dan Perancangan Kontrak. Jakarta: PT. Raja Grafindo Persada, 2016.

[13] D. S. Meliala, Hukum Perdata dalam Perpektif BW. Bandung: Nuansa Aulia, 2014.

[14] K. Muljadi and G. Widjaja, Perikatan Yang Lahir dari Perjanjian. Jakarta: PT. Rajagrafindo Persada, 2010

[15] H. Budiono, Kumpulan Tulisan Hukum Perdata Di Bidang Kenotariatan Buku Kesatu. Bandung: PT. Citra Aditya Bhakti, 2016.

[16] H. Budiono, Asas Keseimbangan bagi Hukum Perjanjian Indonesia (Hukum Perjanjian Berlandaskan Asas-Asas Wigati Indonesia). Bandung: PT. Citra Aditya Bakti, 2015.

[17] M. D. Badrulzaman, Hukum Perikatan dalam KUHPerdata Buku Ketiga, Yurisprudensi, Doktrin, serta Penjelasannya. Bandung: PT. Citra Aditya Bakti, 2015. 